\title{
Irreversible, uselektive monoaminoksidasehemmere
}

\author{
Irreversible, uselektive monoaminoksidasehemmere (MAO-hemmere) \\ var blant de første legemidlene som ble utviklet mot depresjon. I Norge \\ er ingen legemidler i denne gruppen markedsført, men siden de brukes \\ en del på registreringsfritak, vil mange leger komme i kontakt med \\ pasienter som bruker midlene. I denne artikkelen presenteres lege- \\ middelgruppens bivirkninger og interaksjoner samt hvilke forholds- \\ regler som må tas ved bruk av midlene.
}

Se også kunnskapsprøve på www.tidsskriftet.no/quiz

De antidepressive legemidlene fenelzin (Nardil), tranylcypromin (Parnate) og isokarboksasid (Marplan) er irreversible og uselektive hemmere av enzymet monoaminoksidase (MAO). Midlene er ikke markedsført i Norge, men fremfor alt fenelzin forskrives $i$ en viss utstrekning på registreringsfritak.

Enzymet monoaminoksidase (MAO) finnes i to former, MAO-A og MAO-B. MAOA inaktiverer i første rekke serotonin og noradrenalin, men også tyramin og andre sentralstimulerende og vasoaktive aminer. MAO-B inaktiverer dopamin. Fenelzin, tranylcypromin og isokarboksasid blokkerer både MAO-A og MAO-B. Dette fører til en økning av nivåene av serotonin, noradrenalin og dopamin, i første rekke i synapsespaltene i sentralnervesystemet, men også ved de respektive reseptorene i perifere vev. Halveringstiden til midlene er fra én til noen få timer, men fordi de blokkerer enzymet irreversibelt, må kroppen produsere nytt enzym før enzymaktiviteten normaliseres. Dette tar omtrent to uker.

\section{Materiale og metode}

Artikkelen er basert på forfatternes egen erfaring innen feltet, supplert med ikke-systematiske litteratursøk i PubMed.

\section{Bivirkninger}

De fleste bivirkningene skyldes økte nivåer av serotonin i sentralnervesystemet og er således de samme som er kjent fra behandling med selektive serotoninreopptakshemmere. Mange av bivirkningene er relativt milde og vil bedres spontant selv om behandlingen kontinueres, mens andre er alvorlige og potensielt livstruende (1-4).

En av de alvorligste bivirkningene er hypertensiv krise, som blant annet kan føre til hjerneødem og intrakranial blødning med fatalt utfall hvis ikke adekvat behandling iverksettes umiddelbart. Pasientene må der- for følges opp med regelmessige blodtrykkskontroller, hyppig til å begynne med og deretter sjeldnere. De aller fleste tilfellene av hypertensiv krise er rapportert hos pasienter som har inntatt spesielle matvarer eller brukt interagerende legemidler. Symptomene er kraftig hodepine, eventuelt med nakkestivhet, kvalme eller oppkast, svette, synsforstyrrelser, psykomotorisk uro og varierende grad av nevrologiske utfall (1-4).

Også mindre alvorlige endringer i blodtrykk, både hypertensjon og ortostatisk hypotensjon, kan forekomme. Eksisterende hypertensjon og alvorlig kardiovaskulær eller cerebrovaskulær sykdom anses for å være en kontraindikasjon for bruk av MAO-hemmere.

En annen alvorlig bivirkning er serotonergt syndrom (5). Symptomene er i hovedsak psykiske (forvirring, uro, agitasjon, delirium, koma), nevromuskulære (tremor, hyperrefleksi, myoklonus, ataksi, kramper) og autonome (kraftig svette, høy feber, diaré, takykardi, takypné). I sin fulminante form kan syndromet være livstruende og kreve intensivbehandling. Det oppstår i all hovedsak når $\mathrm{MAO}$-hemmere kombineres med andre legemidler som virker ved å øke serotoninaktiviteten i synapsene i hjernen.

\section{Interaksjoner med mat og drikke}

Hemmingen av MAO-A medfører at tyramin, som finnes i visse matvarer, ikke blir inaktivert $\mathrm{i}$ tarmveggen og leveren før det når systemsirkulasjonen. Dermed vil tyramin frigjøre noradrenalin fra nerveterminaler nær blodkar. Når heller ikke noradrenalin kan inaktiveres på vanlig måte, fører dette til perifer vasokonstriksjon med blodtrykksøkning og eventuelt hypertensiv krise som resultat.

Tyramin dannes fra aminosyren tyrosin. Det er mye tyrosin i proteinrik kost, som kjøtt, fisk og ost. Når slik mat lagres, omdanner mikroorganismer tyrosin til tyramin. Matvarer som har gjæret over lang tid inne- holder tyramin naturlig. Tyramininnholdet $\mathrm{i}$ en del mat og drikke er gjengitt $i$ tabell 1 (6-9).

I kontrollerte studier har den gjennomsnittlige tyramindosen som trengs for å øke systolisk blodtrykk med $30 \mathrm{~mm} \mathrm{Hg}$ vært 8-33 mg (9). Basert på kasuistikker er det anslått at et inntak av 8-20 mg tyramin kan være nok til å utløse en svært kraftig blodtrykksstigning (9). Det er store variasjoner i tyramininnholdet $i$ en og samme matvare, og det eksakte tyramininnholdet i en gitt porsjon mat kan derfor ikke forutsies (6-8). For å være på den sikre siden, bør en rekke matvarer og drikkevarer unngås eller kun inntas i små mengder (fig 1):

- Oster som har gjennomgått en modningsprosess eller vært lagret i lengre tid. Blåmuggost (Norzola, Saga, blå Castello, roquefort m.fl.) og hvitmuggost (camembert, brie m.fl.) bør unngås helt. Vellagrede/ modnede gule oster som cheddar, edamer og mozarella bør inntas med stor forsiktighet.

- Kjøtt og fisk som er behandlet med røyking, salting, tørking og/eller lengre tids lagring. Kjøttvarer som salami, spekepølse, spekeskinke og fenalår samt fisk som er gravet, raket eller røykt, bør unngås. Det samme gjelder spekesild, alle typer sild i lake, samt ansjos og gaffelbiter.

- Enkelte andre matvarer. Lever av kylling og storfe, ølgjær, buljongpulver, soyasauser og avokado bør unngås. Noen pasienter kan ha fått beskjed om at de skal unngå sjokolade, yoghurt og banan, men dette er ikke nødvendig.

- Visse typer drikke. Sherry og portvin kan inntas i små mengder, og inntak av 1-2

\section{Hovedbudskap}

- Pasienter som bruker irreversible, uselektive monoaminoksidasehemmere må ikke spise lagret, tørket eller gjæret mat, da inntak av slike matvarer kan utløse en livstruende hypertensiv krise

- Legemiddelgruppen har viktige interaksjoner med en rekke andre legemidler

- Pasientene bør utstyres med lister over hvilke matvarer og legemidler de må unngå og alltid opplyse om at de bruker en MAO-hemmer ved besøk hos lege/ tannlege 
glass rødvin eller hvitvin er akseptabelt Kombinasjonen ost og vin vil av naturlige grunner by på spesielle problemer. Fatøl bør unngås, men øl på boks og i flaske kan inntas i små mengder (i størrelsesorden 0,33 1). Det samme gjelder alkoholfritt $ø l$ og vin.

\section{Interaksjoner med legemidler}

Den irreversible enzymhemmingen medfører at interaksjoner med andre legemidler ikke bare kan oppstå under pågående bruk, men også de første to ukene etter seponering av MAO-hemmeren.

\section{Serotonerge legemidler}

Alle legemidler som hemmer reopptak av serotonin fra synapsespaltene i hjernen gir

\begin{tabular}{|c|c|}
\hline Matvare/type drikk & $\begin{array}{l}\text { Innhold av tyra- } \\
\mathrm{min}(\mathrm{mg} / 100 \mathrm{~g})\end{array}$ \\
\hline \multicolumn{2}{|l|}{ Oster } \\
\hline Roquefort & $1-50$ \\
\hline Brie & $0-50$ \\
\hline Camembert & $0-150$ \\
\hline Cheddar & $1-50$ \\
\hline Edamer & $10-20$ \\
\hline Gorgonzola & $5-80$ \\
\hline Mozarella & $2-40$ \\
\hline \multicolumn{2}{|l|}{ Kjøttvarer } \\
\hline Kyllinglever & 10 \\
\hline Okselever & $0-30$ \\
\hline Salami & $0-100$ \\
\hline Pepperoni & $0-20$ \\
\hline \multicolumn{2}{|l|}{ Fiskeprodukter } \\
\hline Kaviar & 70 \\
\hline Sursild, kryddersild etc. & 300 \\
\hline \multicolumn{2}{|l|}{ Andre matvarer } \\
\hline Avokado & $0-20$ \\
\hline Bananer, skall & $5-7$ \\
\hline Bananer, fruktkjøtt & $0-1$ \\
\hline Gjær & $10-300$ \\
\hline Sauerkraut & $5-6^{1}$ \\
\hline Soyasaus & $0-90$ \\
\hline \multicolumn{2}{|l|}{ Drikke } \\
\hline Champagne & $0-1,8^{2}$ \\
\hline Hvitvin & $0-0,6^{2,3}$ \\
\hline Portvin & $<0,2^{2}$ \\
\hline Rødvin & $0-0,9^{2,3,4}$ \\
\hline Sherry & $<0,4^{2}$ \\
\hline$\emptyset l$, flaske/boks & $0-12,3$ \\
\hline$\emptyset l$, fat & $2-10^{2}$ \\
\hline
\end{tabular}

Gjelder den gjærede varianten, ikke vanlig surkål 2 Innhold per $100 \mathrm{ml}$

${ }^{3}$ Gjelder også de alkoholfrie variantene

${ }^{4}$ Italienske Chianti-viner inneholdt tidligere inntil $2,5 \mathrm{mg} / 100 \mathrm{ml}$. Med moderne produksjonsprinsip per er innholdet i disse vinene nå langt lavere, under $0,5 \mathrm{mg} / 100 \mathrm{ml}$ en kraftig økt risiko for serotonergt syndrom i kombinasjon med en MAO-hemmer. Slike midler er derfor kontraindiserte $(1-4,9)$. Dette gjelder selektive serotoninreopptakshemmere, venlafaksin, duloksetin og trisykliske antidepressiver som klomipramin og amitriptylin. Det er imidlertid også rapportert ugunstige effekter ved kombinasjon med rene noradrenalinreopptakshemmere som nortriptylin, og det er derfor vanlig å kontraindisere alle trisykliske antidepressiver. Også sibutramin og bupropion har serotonerge effekter og bør ikke kombineres med MAO-hemmere.

De fleste serotoninreopptakshemmere har en halveringstid på 1-2 døgn, noe som medfører at det tar 5-10 dager fra seponering til de er ute av kroppen. Derfor skal behandling med en MAO-hemmer ikke startes før 1-2 uker etter seponering av disse midlene. For fluoksetin er det nødvendig med fem ukers intervall mellom seponering og oppstart med MAO-hemmeren. Ved bytte fra en MAO-hemmer til et serotonergt middel må pausen være minst to uker.

Heller ikke johannesurt eller tryptofan bør kombineres med MAO-hemmere, mens litium, mianserin og mirtazapin kan brukes med forsiktighet.

Av opioidanalgetika har petidin og tramadol serotonerge effekter og bør ikke kombineres med MAO-hemmere (9). Kodein og morfin kan brukes med forsiktighet.

\begin{tabular}{|l|l|}
\hline Oster & \\
\hline Blåmuggost (roquefort, Norzola, Saga etc.) & \\
\hline Hvitmuggost (camembert, brie etc.) & \\
\hline Vellagrede gule oster (cheddar, edamer, mozarella etc.) & \\
\hline Kjøttvarer & \\
\hline Lever & \\
\hline Salami, spekepølse, pepperoni etc. & \\
\hline Spekeskinke, fenalår & \\
\hline Fiskeprodukter & \\
\hline Gravet, raket eller røykt fisk & \\
\hline Spekesild & \\
\hline Sursild, kryddersild, annen sild i lake & \\
\hline Gaffelbiter, ansjos & \\
\hline Kaviar & \\
\hline Andre matvarer & \\
\hline Ølgjær & \\
\hline Buljong/buljongpulver & \\
\hline Soyasaus & \\
\hline Avokado & \\
\hline Bananer & \\
\hline Sjokolade & \\
\hline Yoghurt & \\
\hline Drikke & \\
\hline Sherry, portvin & \\
\hline Champagne & \\
\hline Rødvin (inklusive alkoholfri rødvin) & \\
\hline Hvitvin (inklusive alkoholfri hvitvin) & \\
\hline Fatøl & \\
\hline$\varnothing \mid$ på boks/flaske (inklusive alkoholfritt øl) & \\
\hline \\
\hline Inntak må unngås & \\
\hline Blen spesielle restriksjoner & \\
\hline
\end{tabular}

Figur 1 Oversikt over mat og drikke som er forbundet med spesielle restriksjoner hos pasienter som bruker irreversible, uselektive MAO-hemmere 


\section{Sympatikomimetika}

Siden en viktig inaktiveringsvei for noradrenalin blokkeres av MAO-hemmere, bør legemidler som virker ved å frigjøre noradrenalin fra nerveterminalene (indirektevirkende sympatikomimetika) ikke kombineres med MAO-hemmere (1-4, 9). Eksempler på slike midler er amfetamin, metylfenidat, efedrin, fenylefrin, fenylpropanolamin og metaraminol. Årsaken til at disse kombinasjonene er kontraindisert, er at det vil oppstå en overstimulering av adrenerge kardiovaskulære reseptorer, med kraftig perifer vasokonstriksjon og blodtrykksstigning som resultat.

Direktevirkende adrenerge agonister til systemisk bruk, som noradrenalin og adrenalin, kan kombineres med MAO-hemmere, men forsiktighet bør utvises. Direktevirkende agonister til lokalbehandling (slimhinneavsvellende nesespray, beta-2-agonister til inhalasjon) kan brukes uten videre.

\section{Andre interaksjoner}

Siden MAO-hemmerne også blokkerer MAO-B, som inaktiverer dopamin, vil det være en økt risiko for dopaminerg overstimulering hvis midlene kombineres med levodopa eller visse andre antiparkinsonmidler. MAO-hemmere har en viss hypoglykemisk effekt, og nøye oppfølging av blodglukoseverdiene er nødvendig hos pasienter som bruker insulin eller andre antidiabetika. Buspiron bør ikke kombineres med MAOhemmere. Antipsykotiske midler, med unntak av levomepromazin, kan kombineres med MAO-hemmere.
Bruk av MAO-hemmere i forbindelse med anestesi er spesielt problematisk, siden det ofte er påkrevd å bruke sympatikomimetika for å opprettholde et adekvat blodtrykk. Det anbefales derfor å seponere MAO-hemmere to uker før anestesi.

\section{Praktiske råd}

Alle pasienter bør utstyres med en liste over matvarer og drikkevarer med restriksjoner samt hvilke legemidler som er kontraindiserte i kombinasjon med MAO-hemmere. Pasientene må instrueres $\mathrm{i}$ at de alltid $\mathrm{i}$ forbindelse med lege- eller tannlegebesøk må opplyse om at de bruker en MAO-hemmer. Ved slike besøk bør de også ha med seg listen over legemidler som er kontraindisert, siden denne typen informasjon ofte er vanskelig tilgjengelig for legen/tannlegen. Flere større psykiatriske avdelinger har utarbeidet skriftlig informasjonsmateriell til pasienter som bruker MAO-hemmere.

\section{Ingrid Castberg}

ingrid.castberg@stolav.no

Psykisk helsevern avdeling Østmarka

St. Olavs hospital

Postboks 3008 Lade

7441 Trondheim

\section{Olav Spigset}

Avdeling for klinisk farmakologi

St. Olavs hospital

og

Institutt for laboratoriemedisin, barne- og

kvinnesykdommer

Norges teknisk-naturvitenskapelige universitet

Oppgitte interessekonflikter: Ingen
Litteratur

1. Monoamine oxidase inhibitors. I: McEvoy GK, red. AHFS drug information 2004. Bethesda, MD: American Society of Health-System Pharmacists, 2004 : 2160-6.

2. Phenelzine. I: Sweetman SC, red. Martindale - The complete drug reference. 35. utg. London: The Pharmaceutical Press, 2007: 375-9.

3. Phenelzine. I: Dollery C, red. Therapeutic drugs 2. utg. Edinburgh: Churchill Livingstone, 1999: P74-7.

4. Tranylcypromine. I: Dollery C, red. Therapeutic drugs. 2. utg. Edinburgh: Churchill Livingstone, 1999: T154-7.

5. Höjer J, Personne M, Skagius A et al. Serotoninergt syndrom - flera allvarliga fall med denna ofta förbisedda diagnos. Tidsskr Nor Lægeforen 2002; 122: 1660-3.

6. Sullivan EA, Shulman KI. Diet and monoamine oxidase inhibitors: a re-examination. Can J Psychiatry 1984; 29: 707-11

7. Brown C, Taniguchi G, Yip K. The monoamine oxidase inhibitor - tyramine interaction. J Clin Pharmacol 1989: 29: 529-32.

8. Gardner DM, Shulman KI, Walker SE et al. The making of a user friendly MAOI diet. J Clin Psych latry 1996; 57: 99-104

9. MAOls. I: Baxter K Stockley's drug interactions. 8. utg. London: The Pharmaceutical Press, 2008: $1130-57$

Manuskriptet ble mottatt 6.4. 2008 og godkjent 12.2. 2009. Medisinsk redaktør Anne Kveim Lie. 